\title{
湾内外の密度差形成時の密度貫入による海水交換
}

\section{Seawater exchange due to density intrusion under different stratification conditions}

\author{
日比野忠史 ${ }^{1} \cdot$ 池田正之 ${ }^{2} \cdot$ 駒井克昭 $^{3}$ \\ Tadashi Hibino, Masayuki Ikeda and Katsuaki Komai \\ ${ }^{1}$ 正会員 博士 (工学) 広島大学工学研究科助教授 社会環境システム専攻(テ739-8527 東広島市鏡山 1-4-1) \\ 2学生会員 広島大学工学部（テ739-8527 東広島市鏡山 1-4-1) \\ 3正会員 工修 広島大学工学研究科助手 社会環境システム専攻(テ739-8527 東広島市鏡山 1-4-1)
}

\begin{abstract}
This paper deals with the seawater exchange caused by density gradient between the outer bay and inner bay using density profile around the bay mouth and velocity profile above the mound. It is revealed that the mechanism of seawater exchange is greatly influenced with the density intrusion depending on the horizontal density gradient. When the density of the outer bay is smaller than the inner bay, the seawater exchange occurs in the upper layer, and can't be expected in the lower water. But, when the density of the outer bay becomes bigger than the inner bay after coming typhoon, the water body of the outer bay intrudes into the lower layer of the inner bay. Therefore, seawater exchange in the lower layer of the inner bay is accelerated.
\end{abstract}

Key Words: Ohfunato Bay, Sill, Sea level height, Flow rate, Density current

\section{1.はじめに}

大船渡湾 (三陸沿岸, $39^{\circ} \mathrm{N}, 141.75^{\circ} \mathrm{E}$ ) は昭和 35 年チリ 津波により甚大な被害を受け, 昭和 42 年には津波防波堤 が設置された. 湾口部(水深約 $40 \mathrm{~m}$ )には高さ約 $20 \mathrm{~m}$ の捨 石マウンドが設置され，湾内外が分離された形状にある. 湾内で温度躍層の形成や有機泥によるバクテリア等の活性 化が起こるために, 晚夏には底層に貧酸素水塊が形成さ れる. 大船渡湾は南北方向が約 $7 \mathrm{~km}$, 東西方向約 $2 \mathrm{~km}$ の 南北に細長い湾であり, 最大水深約 $40 \mathrm{~m}$, 平均水深約 $20 \mathrm{~m}$ の空間スケールを有している. 湾軸に沿って, 水深 $30 \mathrm{~m}$ 以 上の淵が湾央まで続いている. 湾奥部には, 日平均流量 $2.6 \mathrm{~m}^{3} / \mathrm{s}$ の流量規模の盛川が流れ込んでいる. 湾口部には, 津波防波堤が建設されており, その開口部には, 水深約 $16 \mathrm{~m}$ のところに長さ $200 \mathrm{~m}$, 幅 $90 \mathrm{~m}$ の捨石マウンドが存在し ている. また, 湾口から約 $1 \mathrm{~km}$ 地点で約 $90^{\circ}$ に屈曲する地形 となっている. なお, 大船渡湾の平面形状と本論文で用い たデータの観測点は論文末(Fig.6)に示されてあるので参 照されたい.

これまでの観測から湾軸に直行する断面では水温·塩分 は一様に分布しており, 軸方向においても湾口部付近をの ぞいて潮汐の影響は小さいこと, 湾軸方向の潮汐に伴う流 れは屈曲部付近までは流速が小さく, 屈曲部を越えてから
流速が大きくなり始め, マウンド上で最大となっていることが わかっている1

本論文では, 湾口マウンド上で測定された流速プロファイ ルおよび湾内中央, 湾口,湾外で測られた水温・塩分プロフ アイルを用いて湾内への流出入量と水位, 密度等の関係か ら海水交換に及ぼす湾内外の密度変化の影響について検 討を行った.

\section{2. 湾内外の成層状態と水位の季節変動}

(1) 湾内外での水温·塩分プロファイルの経時変化

Fig.1には湾内中央と湾外 (マウンドから約 $400 \mathrm{~m}$ 沖) で 1999年3月 18 日〜 9月 24 日に係留測定された水温と塩分の プロファイルおよび湾内水深 $30 \mathrm{~m}$ でのDOと水温の経時変 化が示されている. 水温·塩分センサ一の係留水深は湾内 の $2 \mathrm{~m}, 10 \mathrm{~m}, 16 \mathrm{~m}, 27 \mathrm{~m} と 30 \mathrm{~m}$ おび湾外の $2 \mathrm{~m}, 16 \mathrm{~m}, 25 \mathrm{~m}$ と $35 \mathrm{~m}$ である. 水温·塩分プロファイルは日平均值が示されて いる1).

Fig.1から, (1-1;湾内に比較して湾外において1週間程 度の水温·塩分変動が顕著に現れているものの, 湾内外の 水温·塩分の季節的な変化の傾向は良く対応していること, (1)- 2 ;湾外水温の上昇は湾内水温上昇より早期に起こって いること，(2)-1;4月頃から湾外で塩分が低下し始め, 湾内 


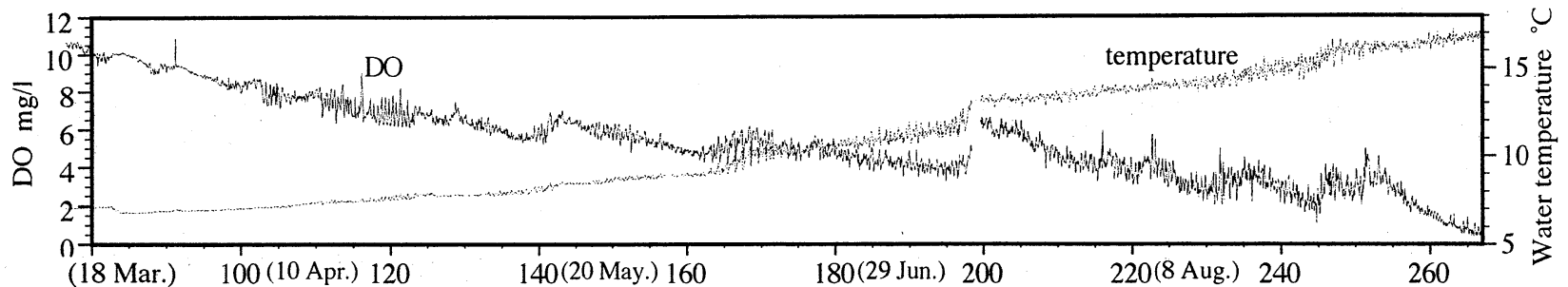

(a) DO, temperature at $30 \mathrm{~m}$ depth in Ohfunato Bay

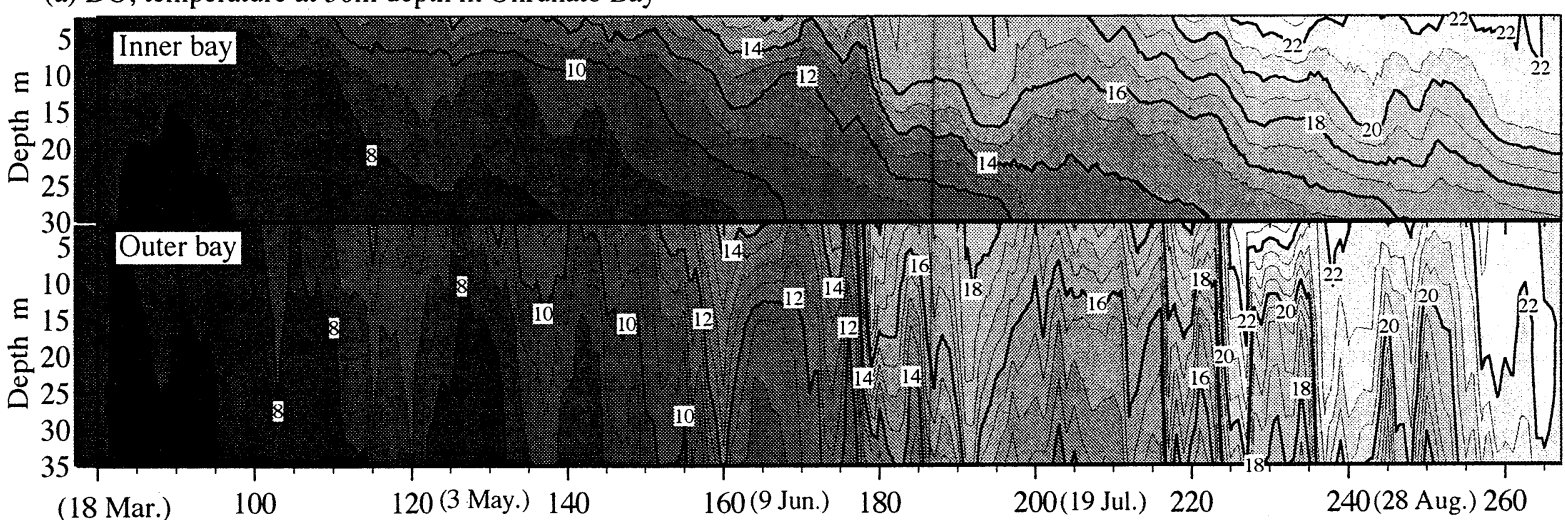

(b) water temperature profile

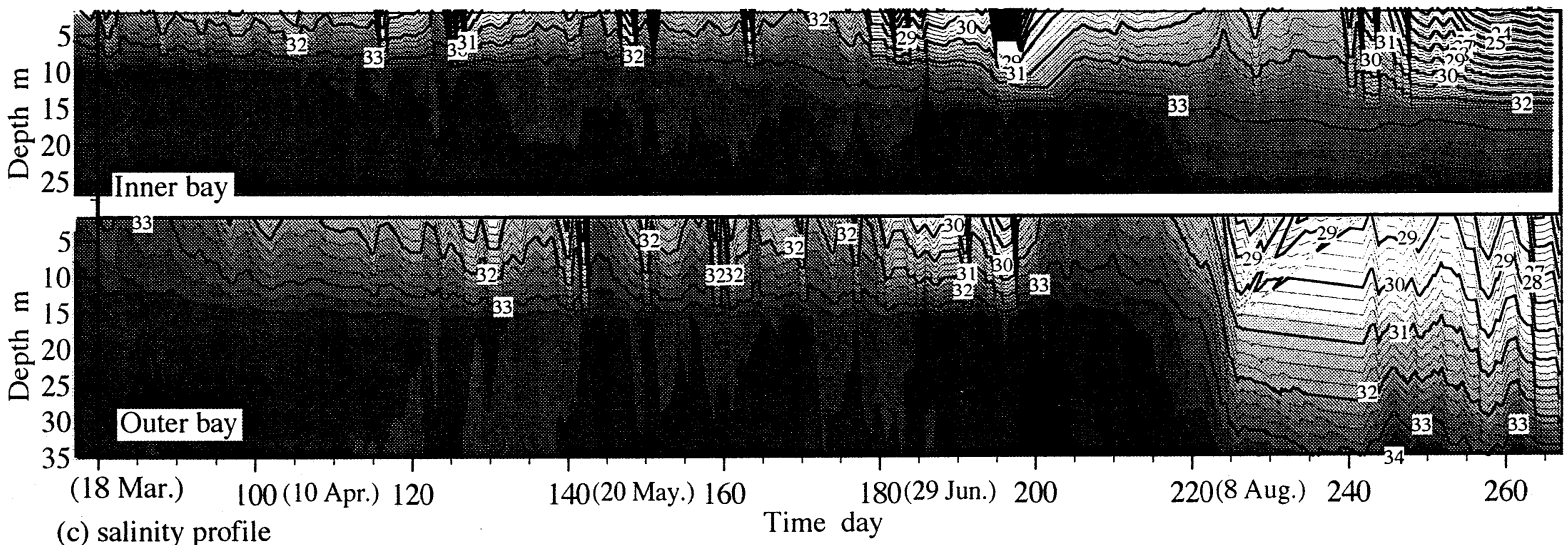

Fig.1 Time series of DO and water temperature ( $35 \mathrm{~m}$ depth inner bay), water temperature and salinity profile at inner bay and outer bay (18 Mar. - 24 Sep. 1999)

では上層の水温が上昇し,躍層の形成が始まっていること， (2)-2;6月頃からの湾外での塩分の上昇に伴って躍層が急 激に発達していること, (2)-3; 躍層の形成に伴って湾内中 層の塩分の低下が観測されていること, (3)7月中旬頃湾外 での塩分低下(台風 4 号が起因)とその後の塩分上昇により DOの急激な回復が起こっていることがわかる.

これらの現象の発生は, 湾内成層が湾外水の流入と関連 が強いためであり, 大船渡湾に接岸する水塊が異なる海流 系の水塊であること, 湾周辺にもたらされる台風や低気圧 によって湾内外の水塊に密度差が生じることに依るもので ある. 上記の(1)一(3)の現象は著者らのこれまでの研究から， 湾外水塊の湾内貫入による海水交換機構 ${ }^{2)}$ (1), (2)), 成層 期におけるDO の回復機構1)(3) によって説明がつけられ る.

（2）湾ロマウンド上での流速プロファイル

Fig. 2 に 1999 年7月 19 日〜 10 月 27 日に防波堤マウンド
上で超音波ドップラー流速計（スタンドアローン型， $0.5 \mathrm{MHz}:$ NORTEK 社製, 以下 ADP)により測定された(a)流 速の鉛直プロファイルおよび同時期の(b)湾内外での水温 プロファイル, (c)河川(盛川)流出量, 湾口での日平均流出 量の日変化が示されている. 流速の観測間隔は 5 分, 1 分 間の平均值を観測值としており, 湾内一の流入流速を正と している. 流速プロファイルのパターンは湾内外の水温プ ロファイルによって変化していることがわかる. 湾外水温の 低い時には下層からの流入パターン, 湾外水温が高くなる と上層からの流入パターンになっている. 湾内の躍層消滅 後は, 常に下層からの流入が起こっている(エスチャリー循 環が卓越). 岡田ら ${ }^{2)}$ は, 湾外水の湾内一の密度貫入によ って湾内の密度(水温·塩分)プロファイルを再現している. この考えにもとづけば, 水温の低い湾外水塊は湾内下層 一貫入し, 湾外水塊の水温が高くなると上層へ流入(湾内 上層水塊の湾外下層への流出)することによって上記の湾 


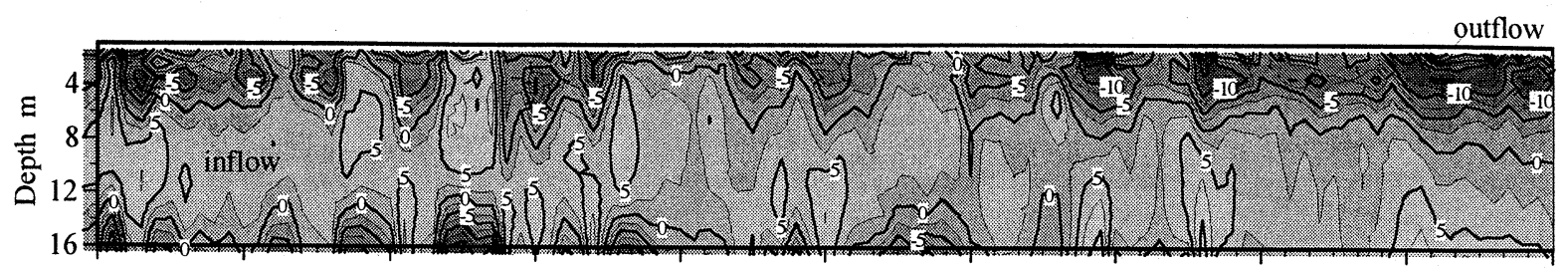

(a) velocity profile above the mound at bay mouth (+; inflow)

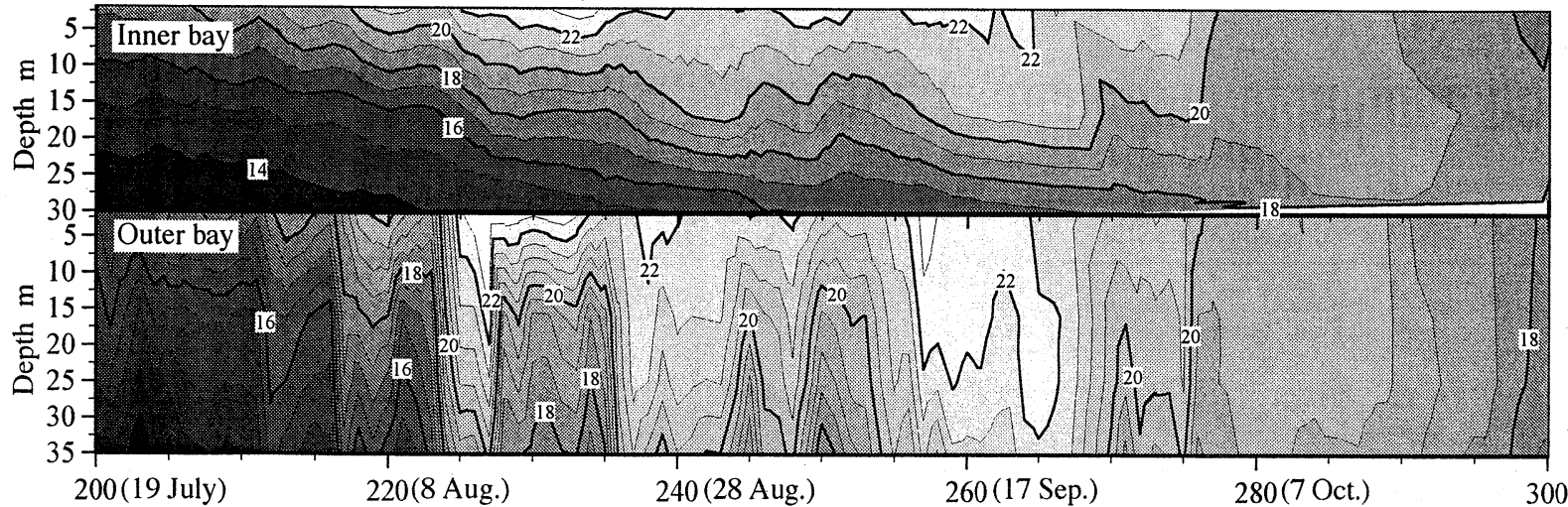

(b) water temperature profile

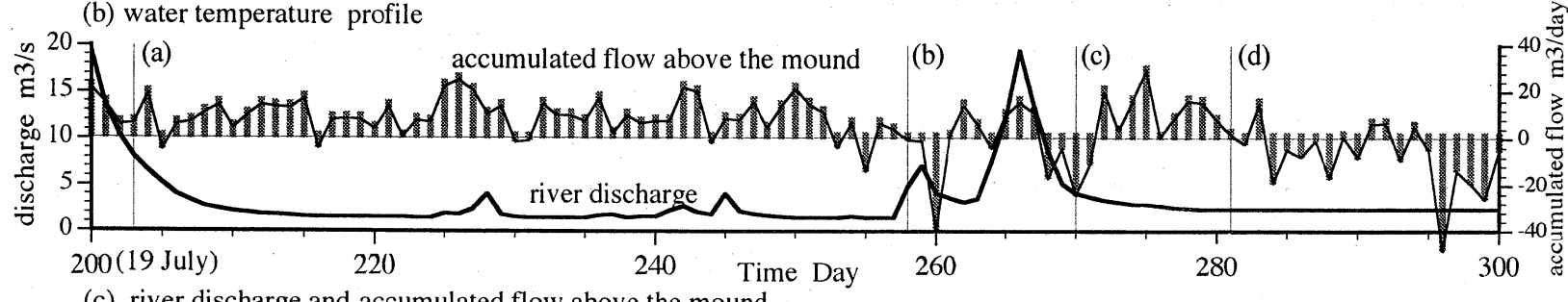

(c) river discharge and accumulated flow above the mound

Fig.2 Daily changes of velocity profile above the mound at bay mouth, water temperature profile at inner bay and outer bay and discharge (19 July - 27 Oct. 1999) ((a)-(d) in fig.(c) show the periods described velocity profiles in Fig.4)

ロマウンド上での流れが起こっていると考えられる.

先ず河川流出量の湾内水流出一の影響について検討す る. $20 \mathrm{~m}^{3} / \mathrm{s}$ の河川流出が 24 時間継続すると仮定すれば, 大船渡湾の水位を約 $40 \mathrm{~cm}$ 上昇させる. 湾口 (幅 $200 \mathrm{~m}$ )での 流出入量と比較すると洪水時には 100 倍以上の河川流出 がある. 洪水時には $10 \mathrm{~m}^{3} / \mathrm{s}$ を越える河川水が湾内に流出 して, 湾口部では流入傾向にある. これは, 河川水が湾表 層をプリュームしして湾外に流出していく(ADP では表層流 速を正確にとらえていないためにこの現象は捕捉できてい ない)ためで, これに伴ったエスチヤリー循環により湾外水 が流入していると考えられる.このような現象が起こることで 洪水後の上層流出にともなって海水交換が促進されている ことが推測できる(Fig.2(C)).ちなみに, 湾口部上層からの $10 \mathrm{~cm} / \mathrm{s}$ を超える流出傾向は湾内中層水温が上昇する 9 月 以降の洪水後に現れている. また, 280 日以後(躍層消滅 後)の流出傾向は風との対応(吹送流)がある.

(3)湾内外の水温分布と湾口部での流況

Fig.3 には(a)流速プロファイルから求められた湾内流出 入量の累積值(水位換算值) と湾内 DO, (b) 北北西-南南 東方向の風 (卓越風), (c) 湾外水位 (気圧変動分を除去, 水位変動量は気圧効果が静的に働 1013-SLP によって算出 $\left.{ }^{3)}\right)$ と湾外下層密度から求められた 換算水位, (d)湾内外の平均密度が示されている. 平均密
度は塩分観測データの信頼性の高い湾内外の 3 水深 $(2 \mathrm{~m}$, $16 \mathrm{~m}, 30 \mathrm{~m}$;湾内, $35 \mathrm{~m}$; 湾外)の水温・塩分データから求め られた. なお, 水深 $2 \mathrm{~m}$ デー夕は上層 $6 \mathrm{~m}$ まで, $16 \mathrm{~m}$ データ は6ー20m まで, $30 \mathrm{~m}$ と $35 \mathrm{~m}$ は $20 \mathrm{~m}$ 以深の代表值ししてい る. 密度功の水位換算は 1997〜99 年に観測された湾外 水深 $35 \mathrm{~m}$ での水温·塩分の時系列デー夕と気象庁によって 行われた 1990〜 98 年の海洋観測資料(CTD ゙ータ)をもと に求められた次式によって行われている31.

$$
\mathrm{V}_{2}=\left(\rho_{1}-\rho_{2}\right) \mathrm{V}_{1} / \rho_{2}
$$

ここに, Vは水塊の体積, $\rho$ は密度, 添え字 1,2 は各々黒 潮系水塊および浸入前の水塊を表す（観測結果から $\left.\rho_{1}=1025.54 . \mathrm{kg} / \mathrm{m}^{3}\right)$. また, 流速プロファイルからの水位は 累積流量を大船渡湾の表層 $3 \mathrm{~m}$ 未満以浅の平均面積 4.58 $\times 10^{6} \mathrm{~m}^{3} / \mathrm{m}$ で除して換算されている.

Fig.3 から(1)本観測期間での湾口を通過する累積流量 (残差流量)による水位変化量は数 $\mathrm{cm}$ であり, 水位変動量 の $1 / 10$ 程度であること,(2)北北西の風(季節風)が吹き始め るとともに湾内の成層が消滅し, DO の急激な増加が観測さ れていること, (3)-1;湾外水位は湾外密度の換算水位と対 応して変動しており, 換算水位は湾外水位の下限值を連ね ていること, (3)-2;湾外水位と湾外密度の換算水位に差が 


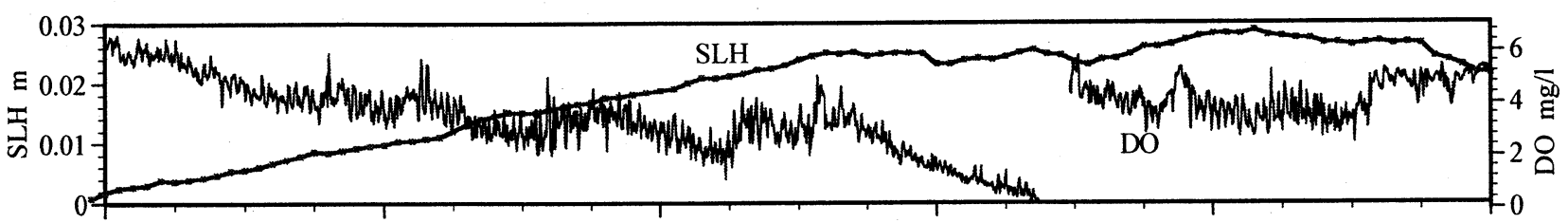

(a) accumulated inflow from outer bay (SLH) and DO at 30m depth in the bay

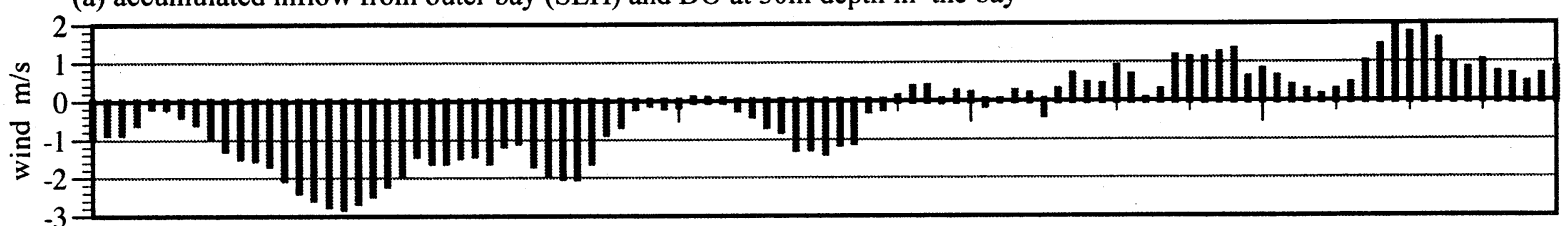

(b) NNW-SSE wind (+;NNW, -;SSE)

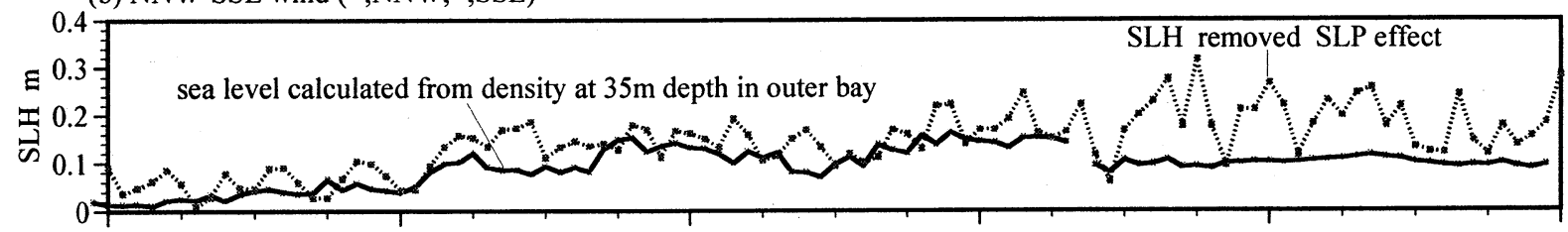

(c) observed and estimated SLH

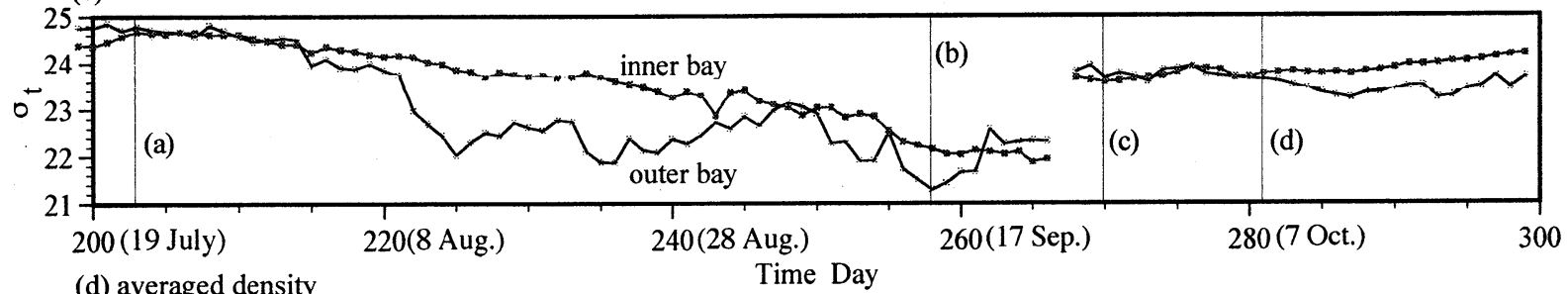

(d) averaged density

Fig.3 Time series of meteorological element and water qualities at inner bay and outer bay (19 July - 27 Oct. 1999)

((a)-(d) in fig.(d) show the periods described velocity profiles in Fig.4)

生じるのは北北西の風が吹き始めた後であること, (4)-1;湾 内外の密度差の大きい(湾外で密度小さい)時期に高水温 水塊がマウンド上層から流入していること, (4)-2; 湾内外の 密度差小さい時期には湾外水塊はマウンド上の下層から 流入していることがわかる.

(1)の現象は外海水の移流による水位変動が小さく, 海水 交換による密度変化によって季節的な水位変化が起こって いる(Fig.2(c))ことを示している. (1)と(4)から, 湾内水塊の 交換は潮汐によって起こる湾内外の水塊交換が主な要因 であり, 交換時に密度貫入が起こることによって湾内外の水 塊が相互の異なる水深に浸入することで効率の良い交換 が行われていることが推測できる.ここで, 低層 DO の上昇 はDOを多く含む密度の大きな外海水が湾内下層に浸入し ていることを示している.

(2)および(3)に示すように, 季節風 (大船渡湾では NNW-SSE 方向の風が卓越し, 秋一冬にNNW の風が吹く) とともに水位上昇量が大きくなる.さらに, 低水温(高密度) の外海水塊が湾に流入することによって, 湾内の成層を壊 している. 以上のように内湾の水質の変化と季節の関係は 深く, 気象・海象を考慮した内湾の水質を検討寸る必要が ある.

\section{3．潮位変動に伴う湾口での流れ場}

Fig. 4 には 1999 年の $(\mathrm{a}-1) 7$ 月 22 日 9:00, $(\mathrm{a}-2) 11: 00 ，$ $(\mathrm{a}-3) 13: 00,(\mathrm{~b}-1) 9$ 月 15 日 $16: 00,(\mathrm{~b}-2) 18: 00,(\mathrm{~b}-3) 20: 00$ ， (c-1)9月27日2:00，(c-2)4:00，(c-3)6:00および(d-1)10月8日 13:00, (d-2)15:00, (d-3)17:00に観測された湾内 (St.a)〜マ ウンド〜湾外(St.c)の密度((b)は水温) 分布およびマウンド 上の流速プロファイルが示されている. いずれの時期も上 げ潮一満潮一下げ潮に対応するプロファイルが示されて いる. 図中の值は30分間の平均値(密度は3回, 流速は6回 の測定結果)が示されている.これらの期間(Fig.2(c)と Fig.3(d)中の縦線) は湾外での平均密度が大きい時期(a), 湾外で密度の小さい時期(b), 洪水直後(c)および密度成層 消滅期(d)の潮汐に伴ったマウンド上での流速プロファイル と密度(水温)分布について示している.

\section{（1）湾内外の密度差と湾内への流出入機構}

マウンド上での流れは各時期で異なっており, 湾内外の 密度差が流れを支配していることがわかる. 湾外で密度が 大きい期間(a)では上下層逆の流れ (上層で流出, 下層で 流入)が生じている. 湾口下層から流入した水塊は湾内下 層の等密度層に貫入し, 湾内中下層の水温を上昇させて いる(Fig.2(b)). さらに, 下げ潮時においても湾口中層から 湾内一の流入がある. (c)の期間は湾内上中層の低密度化 が起こった後であり, 湾外に外海水が接岸することにより湾 内外の密度差は大きくなる. 湾内外の密度差が大きくなる と, 湾口下層の流孔は潮の干満によらず流入し, 湾外水の 密度貫入は常時起こっている ${ }^{4)}$. 湾外で密度が高い期間は 湾外水の下層貫入により, 湾内底層水塊の交換が促進され 

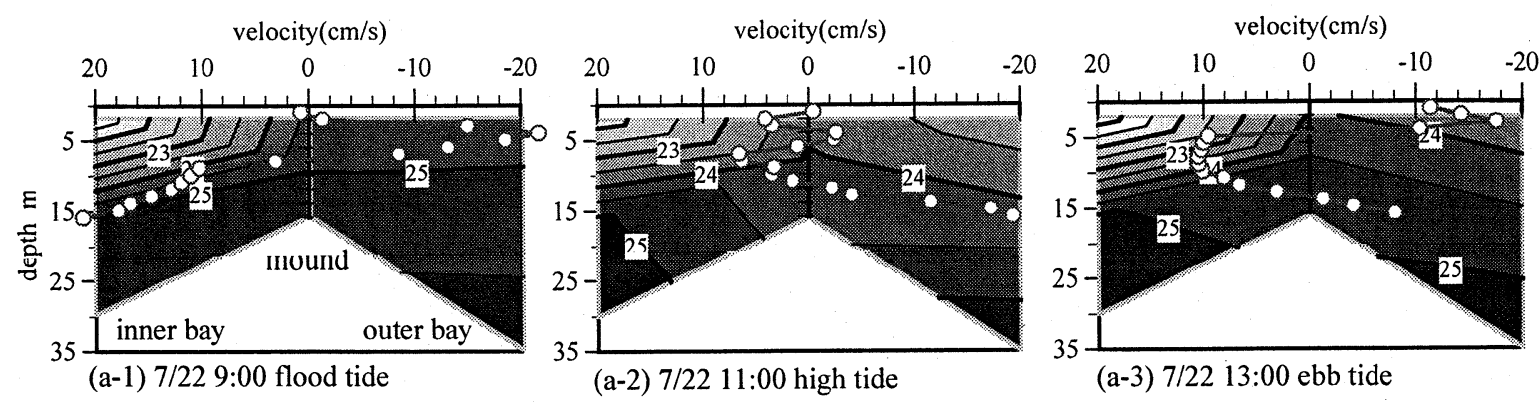

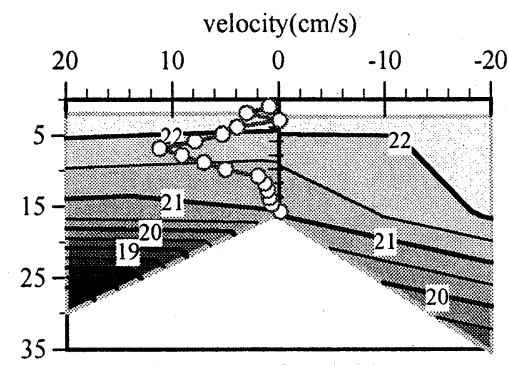

(b-1) 9/15 16:00 flood tide

velocity $(\mathrm{cm} / \mathrm{s})$

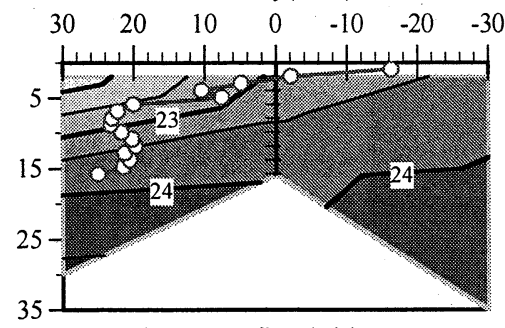

(c-1) 9/27 2:00 flood tide velocity $(\mathrm{cm} / \mathrm{s})$

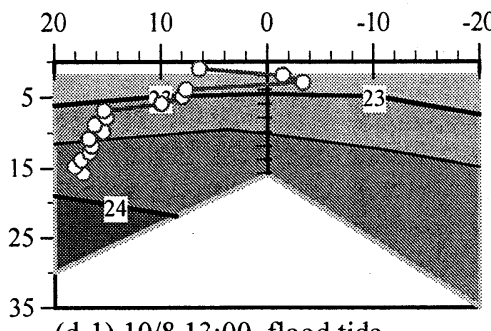

(d-1) 10/8 13:00 flood tide

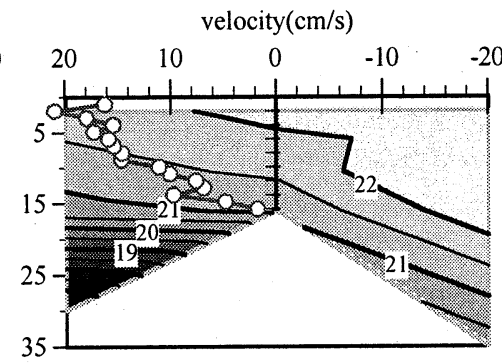

(b-2) 9/15 18:00 high tide velocity $(\mathrm{cm} / \mathrm{s})$

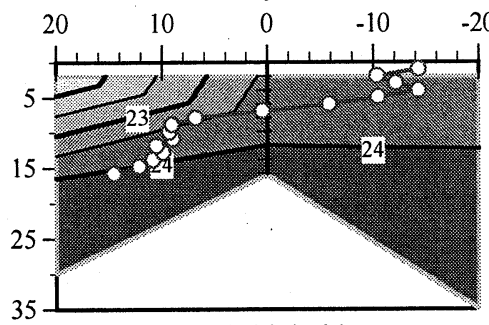

(c-2) 9/27 4:00 high tide

velocity $(\mathrm{cm} / \mathrm{s})$

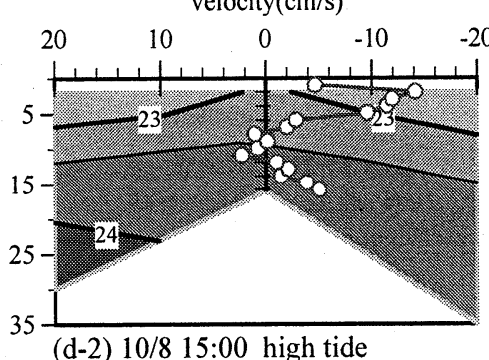

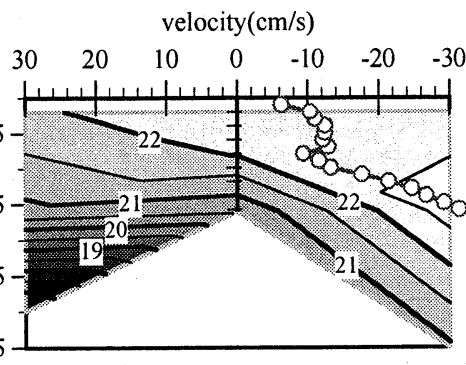

(b-3) 9/15 20:00 ebb tide velocity $(\mathrm{cm} / \mathrm{s})$

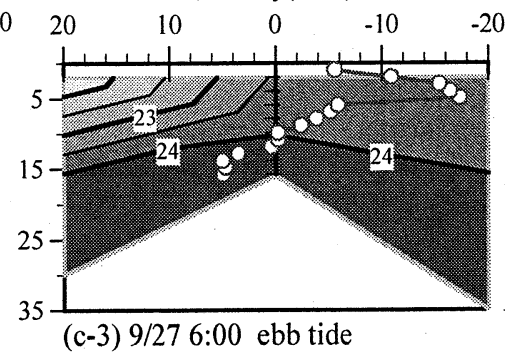

velocity $(\mathrm{cm} / \mathrm{s})$

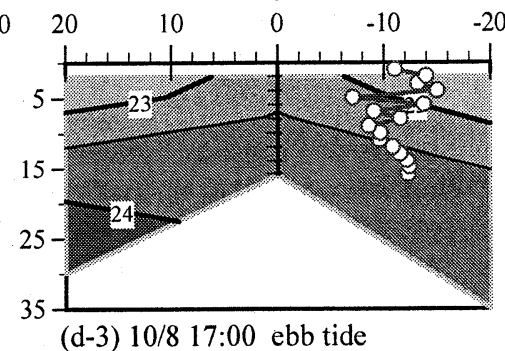

Fig.4 Velocity profile above the mound at bay mouth, density ((b) water temperature) profile at inner bay - bay mouth outer bay from flood tide to ebb tide

ていることがわかる.

湾内よりも湾外の密度が小さい(水温が高い) 時期((b)お よび(d))には, 湾内外の密度の分布状況によって湾口での 流れのパターンが異なっている. 湾内外の密度差が大きい 時期(b)には，上げ潮時に湾口上層からの流入，下げ潮時 には下層からの流出が卓越している.（b) の期間には，湾 内DOの消費が観測されており下層にDOを供給するため の海水流動は起こっていない.この期間の密度状態では 湾内上層水塊の交換が顕著になり, 下層水塊の交換は期 待できない.

また（d)の期間に上層で常に流出が起こつているのは， 表層密度が湾内で小さいことに起因する. さらに, マウンド 上で密度が高くなるのは, 下げ潮 (湾口下層で流出) 時に 起こる内部波によって湾内の底層水塊が湾外に排出された
ためである ${ }^{5)}$.この時期(湾内での成層が弱い)の海水交換 は湾外水の密度貫入に依らず, 中層での混合や,これによ って促進される下げ潮時の内部波に伴う下層水塊の湾外 排出に依る海水交換が卓越しているものと考えられる.

\section{（2）潮汐に伴った海水交換量の推定}

Fig.5(a)〜(d)には, Fig.4 に示した期間に対応する潮汐 の前後 1 潮汐分の水位変化と湾口マウンド直上の下層(8〜 $16 \mathrm{~m})$ および上層(0～8m)の流出入量との関係が示されてい る. 湾外での密度が大きい期間(a), (c)では, 湾口部下層か りの流入, 上層からの流出が支配的であ,るのに対し, 湾外 の密度が小さい期間(b)と密度成層消滅期(d)では, 上層・下 層の流出入量は, ほぼ同位相・同振幅で変動している.

海水交換は(a)と(c)の期間に促進されていることがわかる. 期間(a), (c)では, 重い湾外水が貫入によって湾内の底層 

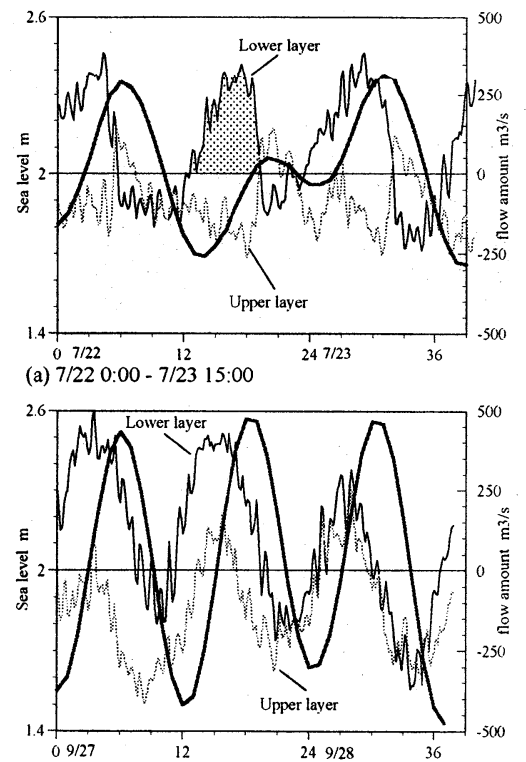

(c) $9 / 270: 00-9 / 28$ 15:00

Fig.5 Relationship between SLH and amount of inflow and outflow

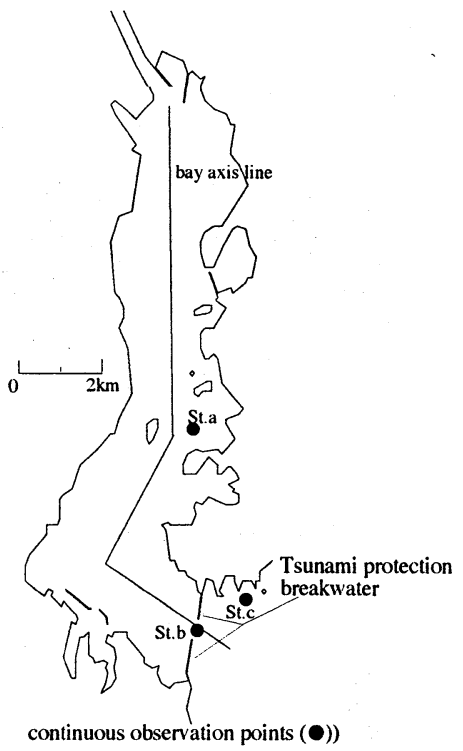

Fig.6 Plan of Ohfunato Bay and ovservation points
に流入している ${ }^{2)}$.この場合には, 湾内上層水が流出し, 流 入量を海水交換量として数えることができる. 例えば, Fig.5(a)の半日潮(ハッチで示した期間)では約 $3.5 \times 10^{6} \mathrm{~m}^{3}$ (大船渡湾内の全水量の $1 / 30$ )の海水交換があったことに なる.

\section{4. おわりに}

貧酸素水塊の形成〜消滅期(7月中旬～10月)に, 湾内外 水の成層状態が起こす湾口部での流れの発生機構と海水 交換について現地観測結果に基づいて検討を行った結果, 以下のことが明らかになった。

(1)湾口での流出入量(残差流量) と比較すると洪水時には 100 倍以上の河川流出がある. 洪水時には $10 \mathrm{~m}^{3} / \mathrm{s}$ 越え る河川水が湾内一流出しているが, 湾口部では湾内上層 水の流出に伴って湾外水が流入する傾向にある. 洪水時 にこの機構により海水交換が促進されている.

(2)湾内水塊の交換は潮汐によって起こる湾内外の水塊交換 が主な要因であり, 交換時の密度貫入に伴って湾外の水 塊が湾内の同密度の水深に浸入していることが効率の良 い交換を進めているものと推測できる.

(3)湾口での流出入 (収支)による水位変化は, 水位変動量 の1/10程度であり，外海水の移流による水位变動量け小 さく, 海水交換による密度変化に伴って, 季節的な水位変 化が起こっている.

(4)湾内外の密度差が大きくなると, 湾口下層の流れは潮の 干満によらず流入し, 湾外水の密度貫入は常時起こって いる. 湾外で密度が高い期間は湾外水の下層貫入により, 湾内底層水塊の交換が促進されている. 台風 4 号来襲後 (7/22)の半日潮では大船渡湾内の全水量の $1 / 30$ の海水
交換があった.

（5）湾内での成層が弱い時期の海水交換は, 湾外水の密度 貫入に依らず，下げ潮時の内部波に伴亏底層水塊の湾外 排出に依る海水交換が卓越してくる.

謝辞:本解析に使用した大船渡湾での観測データは, 1999 年に港 湾空港技術研究所(現、国土技術政策総合研究所)が第 2 港湾建 設局(現 東北地方整備局)の協力により測得したものである. 盛川 の流量データは岩手県水産技術センターから提供を受けている. ここに記して謝意を表す。

参考文献

1）日比野忠史, 豊田政史, 西守男雄, 細川恭史, 鶴谷広一:海面 水位の変動が内湾域の水環境に及ぼす影響一船渡湾での貧 酸素水塊の形成と消滅機構-, 港研報告Vol.38, No.3, pp.3-36, 1999.

2) 岡田知也, 中山恵介, 日比野忠史, 細川恭史, 古川恵太: 大船 渡湾における底層 DO 濃度の変動に及ぼす湾外の影響、海岸 工学論文集第 47 巻(2)、pp.1041-1045, 2000.

3）日比野忠史: 北一西太平洋での水位振動と日本沿岸域での水 位変化特性、海岸工学論文集第 48 巻(2)、pp.446-450, 2001.

1) 日比野忠史, 岡田知也, 中山恵介: 湾内外の密度差に上万湾口 部での流出入機構, 水工学論文集第 44 巻, pp.945-950, 2000.

5) 豊田政史, 日比野忠史, 西守男雄: 大船渡湾での海水交換機構 と自然力を利用した水質管理手法の検討, 水工学論文集, 第 43 巻, pp1079-1084, 1999.

(2001. 10.1受付) 